DOI: $10.2478 /$ lpts-2019-0033

\title{
ECONOMICAL VALUATION OF WAVE POWER PLANT IN THE BALTIC SEA REGION AT PRE-FLEXIBILITY STAGE
}

\section{J. Berins, L. Petrichenko}

\author{
Riga Technical University, Power Engineering Institute, \\ 12-k1 Āzenes Str., Riga, LV-1010, LATVIA \\ E-mail: janis@irbe.apollo.lv, lubova.petricenko@rtu.lv
}

\begin{abstract}
The article deals with free surface gravity waves as one of the alternative energy sources and their use. The potential of the waves and their transformation devices are considered as the main energy use impact factors. The goal of the research is to perform a cost-benefit assessment. The following tasks have been set: to make an assessment of wave potential, to identify the conversion model and turbine, to determine economic criteria taking into account wave and price variability. The article also provides the description of the theoretical valuation of the costs of the mentioned turbine power plant.

Keywords: axial turbine, renewable energy, wave energy, wave length, wave power, wave power plant, wave propelled turbine.
\end{abstract}

\section{INTRODUCTION}

The 21 st century is a period of hasty growth in world population, production and consumption of fossil fuels (FF). World population increased approximately 10 times in the period of 1819-2019 [1]. Such an increase significantly influences global energy demand. Consequently, total world energy consumption in the last 200 years rose about 22 times [2].

According to the World Energy Council calculations [3], coal is the most abounding FF, whose reserve is enough for about 130 years. However, the global climate change poses a problem for the use of energy and especially for the use of FF [4]-[7]. The global use of coal, oil and gas leads to a rapid growth in carbon dioxide emissions. Global energy-related $\mathrm{CO}_{2}$ emissions increased up to $1.7 \%$ in 2018 to achieve a historic value of $33.1 \mathrm{Gt} \mathrm{CO}_{2}$. It was the peak ratio of increase since 2013, and $70 \%$ higher than the average growth since 2010 [6]. Such $\mathrm{CO}_{2}$ growth contributes to the greenhouse effect and global warming. Since the $1880 \mathrm{~s}$, world temperature has increased by about $0.8^{\circ}$ Celsius $\left(1.4^{\circ}\right.$ Fahrenheit) [8]. As a result, observations show a significant increase in the level of natural disasters and imbalance of different water states. Summing up, greenhouse gas emissions need 
to be controlled, and in the world of growing energy demand, renewable energy sources (RES) look like to be the best solution.

Nowadays the European Union (EU) plays the main role in the development of RES. For several years, the EU has been tackling climate change according to the main European policies such as the Renewable Directive 2009/28/EC, Renewable Energy Directive (2018/2001), Energy Efficiency Directive 2012/27/EU, Paris Agreement, etc. The EU is now committed to decreasing greenhouse gas emissions to $80 \%-95 \%$ below 1990 levels by 2050 [4].

As a result, renewable energy has become the top priority in most developed and some developing countries. According to Renewable Energy Statistics [3], the quantity of renewable energy raised overall by $64.0 \%$ between 2007 and 2019, equivalent to an average increase of $5.1 \%$ per year. The most significant source in the EU-28 is wood and other solid biofuels. The next most important contributors to the renewable energy are wind and hydro power. Biogas, liquid biofuels and solar energy make up $7.4 \%, 6.7 \%$ and $6.4 \%$, respectively, of the total share of EU-28 renewable energy produced in 2017. There are currently low levels of tide, wave and ocean energy production. However, the wave energy is a promising energy source. It has the highest potential in terms of energy production, which makes it more interesting to investigate.

Wave energy has several important advantages compared to solar and wind energy. First, waves have a higher energy density [7]-[8]. Second, the wave energy is predictable one to two days ahead because satellites can measure waves in the ocean, which will subsequently affect devices around the coast. This predictability will afford a smaller margin than is often required to support more volatile RES. Third, wave energy does not require land area, driveways and devices to collect energy of a smaller size than devices for wind power.

Wave energy is one of RES, which is the untapped resource and currently is at an early stage of development [7]-[8]. It is estimated that global wave power potential is equal approximately to $1 \mathrm{TW}$, which is an enormous and impressive value. Furthermore, world's potential is 10000-15000 TWh per year [7]. This is nearly the same as the economic potential in the range of wind and hydropower in the world. However, other scientists who have studied the potential of surface water gravity waves in the world have estimated from 8,000 TWh/year till 80,000 TWh/year [9]. According to the Ocean Energy Statistics report of 2018 [10], Europe occupies a leading position in wave energy installation, which is equal to 11.3 MW.

There is a wide range of wave energy technologies. Each technology uses different solutions to absorb energy from waves, and can be applied depending on the water depth and the location [7], [11]-[13]. In recent years, various onshore and offshore projects have been developed, including the Islay plant (Scotland) and the Pico Island plant (Portugal) [11], [14]. Continuing the investigation of the wave energy, many countries have seen some development in the planning, installation, and operation of wave energy converters (WEC). However, the amount of WEC is still at the Research and Development (R\&D) stage. There are a very limited number of WEC devices that are suitable for a commercial pilot demonstration stage [15]. However, since 2008, the European Commission has invested over $190 \mathrm{M} €$ in ocean energy research and innovation through different projects, such as Horizon 2020 and 
Interred programmes [16]. Currently, plans and projects are being developed in the near future to get EU support and private investment for wave energy development [18]. With the rapid development of the technologies of WEC, the wave source will be able to meet partly the demand of energy.

The creation of new wave power plants (WPP) requires considerable material, financial and labor resources. Therefore, a feasibility study should be carried out to determine the proportion of funds for the construction of new WPP and to estimate the payback period of WPP.

The paper focuses on the free surface gravity waves and their potential in the Baltic Sea. Moreover, we developed and described a new turbine type - an axial self-regulation blade hydrokinetic turbine that formed the basis of all calculations. Consequently, the main goal of the paper is to clarify the economic feasibility of the possible construction of marine WPP based on the developed hydrokinetic turbine.

\section{WAVE POTENTIAL OF THE BALTIC SEA}

According to [9], [17], [18], the wave potential of the World Sea with some exclusions is $29500 \mathrm{TWh} /$ year. The Baltic Sea is the large sea, which is bounded by the coastlines of 9 countries. In the Baltic Sea alone, the potential is estimated to be $24 \mathrm{TWh}$ [7]. It should be noted that global processes, such as global climate change, affect the Baltic Sea region and correspondingly wave energy production in the region. The theoretical wave power reserve of the Baltic Sea is calculated to be 1 GW [19]. The EU Strategy for the Baltic Sea was approved in 2009 [20]. The aim of this strategy is to make the area of the Baltic Sea more environmental, energygenerative, attractive and safe.

The potential of the Baltic Sea is actively studied despite the fact that there are more successful aquatories in the world. For instance, scientists Soomere and Eelsalu [22] have described a study of both the theoretical amount of wave energy and its practically available part in a medium-depth aquatorium on the east coast of the Baltic Sea. The 38-year average wave power is $1.5 \mathrm{~kW} / \mathrm{m}$, but in some places it reaches $2.55 \mathrm{~kW} / \mathrm{m}$, in the Gulf of Finland and in the Gulf of Riga $-0.7 \mathrm{~kW} / \mathrm{m}$. The most important factor is that this water area has an uneven distribution of wave energy during the year. The visualization of the medium depth wave power of the Baltic coast is shown in Fig. 1.

The nodal points shown are 3 nautical miles apart. Results of specific wave power have been produced from 37-year period initial data. Unlevel specific wave power results shown depend on the distance of wave propagation and depth at the nodes. To get more accurate wave power data, the exploration should be led to deep water direction.

There are different methods for determining the potential of waves [18], [21], [22]. These methods have gaps [23]. To mitigate the weaknesses of the above methods in the wave power estimation, we propose a Wave Energy Direction Baseline Projection (WEDBP) method [23] whose initial calculations correspond to the classic irregular wave calculations. The method differs from others by selecting basic base directions $+/-22.5^{\circ}$ and by these sectors the specific power and specific 
energy of the node points are summed. Then there are polygons around the node points that cover the area of the aquatorium, if it is necessary to mathematically model additional node points and sum up the results [23]. With WEDBP method it is possible to cover a large area of the aquatorium with a small amount of nodal numbers and therefore input data.

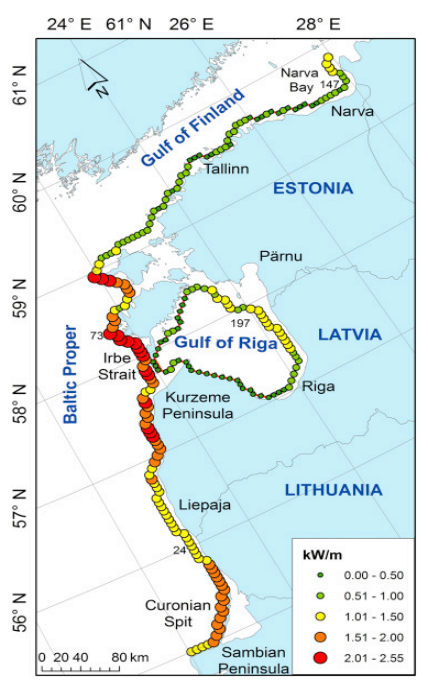

Fig. 1. Visualization of the medium depth wave power of the Baltic coast according to Tarmo Soomere and Maris Eelsalu [18]

Input data used for energy, power and wavelength calculations are significant wave height $\left(H_{s i}\right.$ or $\left.s w h\right)$, wave period $\left(T_{e}\right)$ and mean wave direction ( $\left.m w d\right)$ [10].

Energy calculations were performed by algorithm of the WEDBP method:

From the energy spectrum by integrating in the frequency range $[0$; let us calculate the average wavelength energy density of $J_{\text {vid }}$ in the area of $1 \mathrm{~m}^{2}$ [24]:

$$
J_{v i d}=\rho g \int_{0}^{\infty} S(f) d f=\rho \cdot g \cdot m_{o}=\frac{\rho \cdot g \cdot H_{m 0}^{2}}{16}=\frac{\rho \cdot g \cdot H_{S}^{2}}{16},
$$

where $p$ - Seawater density, $\mathrm{kg} / \mathrm{m}^{3} ; g$ - Free fall acceleration, $\mathrm{m} / \mathrm{s}^{2} ; f$ - wave frequency $(\mathrm{Hz}) ; S(f)$ - wave energy spectrum function; $m_{0}-0$-th spectral moment; $H_{m 0}=H_{s}-$ characteristic wave height, $\mathrm{m}$.

1. In the Baltic Sea Area "A" perpendicular to 8 traditional wind and wave directions $\left(P V_{x \mathrm{x}}\right.$, where $\mathrm{xx}=(\mathrm{N} ; \mathrm{NE}$; E; SE; S; SW; W and NW) let us set the lines perpendicular to those directions.

Thus, summing the wave direction of energy (1) over time interval in each of the node points by sector, the wave energy of non-duplicate directions is counted:

$$
\begin{aligned}
& \dot{\operatorname{E}} n\left(K m, P V_{X X}\right)=\Delta t . \\
& \frac{\rho g^{2}}{64 \pi} \sum_{i=1}^{n} I F\left(m_{w} d_{i}, P V_{X X, \text { min }}, P V_{X X, \text { max }}\right)\left(T_{e i}\left(H_{s i}\right)^{2}\right),
\end{aligned}
$$


where $P V_{x x \min }$ - the minimum limit for basic $P V_{x x}$ sector; $P V_{x x m a x}$ - the maximum limit for $P V_{x x}$ sector; $H_{s i}$ - the significant wave height in the $i$-th time interval, $\mathrm{m} ; T_{e i}-$ the average energy period of wave energy density spectrum, $s$.

The annual wave energy potential of the control point $\mathrm{P}_{\mathrm{m}}$ for a $1 \mathrm{~m}$ wide wave $\dot{\mathrm{E}}_{g}$ is calculated as follows:

$$
\dot{\mathrm{E}}_{g, m, x x, y y}=\sum_{n=1}^{12}\left(E_{n, m, x x, y y}\right) .
$$

2. Integrating the direction of the reference line control points into the corresponding energy by integrating its specific energy function within the distance projection. Thus, the integration process is reduced to the use of trapezoidal method [25], which is as follows:

$$
\begin{aligned}
& E_{x x y y}(K 1, K 5)=\sum_{m=1}^{m+1}=5 E\left(\Delta \mathrm{L}(m, m+1)_{x x}=\right. \\
& \sum_{m=1}^{m+1=5} \frac{\dot{\mathrm{E} n}\left(K_{m}\right)+\dot{\mathrm{E}}_{n}\left(K_{m}+1\right)}{2} \cdot \Delta \mathrm{L}(m, m+1)_{x x}
\end{aligned}
$$

where $m$ - the node point $P_{m, x x}$ serial number $(1,2,3,4,5,7) ; \Delta \mathrm{L}(\mathrm{m}, \mathrm{m}+1)-$ the distances $(\mathrm{m})$ between these point projections on the base line, taking into account the coordinates of the azimuth and control points of the baselines.

3. Knowing the potential of wave energy in the control area where control points P1 are located; P2; P3; P4; P5 and P7, which are marked by the projections of the checkpoints on the base lines of the direction (Fig. 2) and knowing that the control area forms a significant, but not the whole, part of the analyzed area and knowing that the distribution of wave energy in time and space is dispersed homogeneously, it is possible to estimate the amount of $P V_{x x}$ energy for each proportionally increasing ratio of direction of the reference line $P_{n y y}$ and the sum of the respective projection sections of the node points $\mathrm{L}(\mathrm{P} 1, \mathrm{P} 5)_{\mathrm{yy}}$.

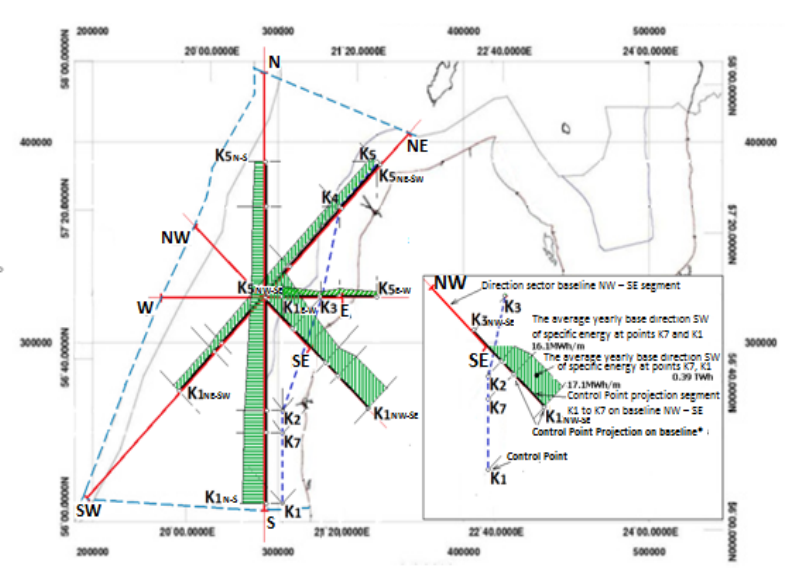

Fig. 2. Wave annual average energy projections in the Baltic Sea area "A" [24], [27]. 
4. As a result of calculation of any aquatorium potential, the total monthly/ annual wave potential is the sum of 8 potentials.

In the Baltic Sea, 7 node points of Latvia's Exclusive Economic Zone (EEZ) were selected, for which we received input data from the Danish Meteorology Institute (DMI) and a number of calculations were made for five years (Table 1).

Table 1

Schedule of the Baltic Sea Latvian EEZ Wave Potential Calculations

\begin{tabular}{|c|c|c|c|c|c|c|c|}
\hline \multirow{2}{*}{ Names of calculations } & \multicolumn{7}{|c|}{ Node points } \\
\hline & $\mathrm{P} 1$ & $\mathrm{P} 2$ & P3 & P4 & P5 & P6 & P7 \\
\hline$E_{\text {monthly }}$ depending on $H_{s i} / T_{e}$ & \multicolumn{7}{|c|}{$2010-2014$} \\
\hline$E_{\text {monthly }}$ depending on $H_{s i} / T_{e}$ & \multicolumn{7}{|c|}{$2010-2014$} \\
\hline$E_{\text {time distribution }}$ & & & & & & 2010 & \\
\hline$P_{\text {specific }}$ depending on $H_{s i}$ & \multicolumn{7}{|c|}{ 2010-2014 } \\
\hline$P_{\text {wave specific }}$ time distribution & \multicolumn{2}{|c|}{$2010-2014$} & & & & & \\
\hline Distribution of waves by $\lambda$ intervals & 2011 & & & & & & \\
\hline$E_{\text {specific }} \mathrm{P} 5$ distr. by $m w d \&$ month & & & & & \multicolumn{3}{|c|}{ 2010-2014 } \\
\hline$E_{\text {specific }}$ P5 distr. by month & & & & & 2010 & & \\
\hline$E_{\text {specific }} \mathrm{P} 5, \mathrm{P} 6, \mathrm{P} 7$ distr. by month & & & & & \multicolumn{3}{|c|}{$2010-2014$} \\
\hline$E_{\text {specific }} \mathrm{P} 6$ distr. by $m w d \&$ month & & & & & \multicolumn{3}{|c|}{$2010-2014$} \\
\hline$E_{\text {specific }} \mathrm{P} 7$ distr. by $m w d \&$ month & & & & & \multicolumn{3}{|c|}{$2010-2014$} \\
\hline
\end{tabular}

Note: $E_{\text {specific }}$ monthly is distribution of wave energy potential by month, kWh; $E_{\text {specific }}$ time distribution is wave energy distribution by time $\mathrm{kWh} / \mathrm{m} ; P_{\text {specific }}$ depending on $H_{s i}$ is wave power dependence of significant wave height, $\mathrm{W} / \mathrm{m} ; P_{\text {specific }}$ time distribution is wave power distribution by time, $\mathrm{W} / \mathrm{m} ; \lambda$ is wavelength, $\mathrm{m} ; E_{\text {specific }} \mathrm{P} 5$ distr. by $m w d \&$ month is specific wave energy distribution by mean wave direction and by month at node point No $5, \mathrm{kWh} / \mathrm{m} ; E_{\text {specific }}$ P5 distr. by month is specific wave energy distribution by month at node point No $5, \mathrm{kWh} / \mathrm{m} ; E_{\text {specific }} \mathrm{P} 5, \mathrm{P} 6, \mathrm{P} 7$ distr. by month is specific wave energy distribution by month at node point $\mathrm{No} 5, \mathrm{kWh} / \mathrm{m}$; No 6 and No 7; $E_{\text {specific }}$ P6 distr. by $m w d \&$ month is specific wave energy distribution by mean wave direction and by month at node point No $6, \mathrm{kWh} / \mathrm{m} ; E_{\text {specific }} \mathrm{P} 7$ distr. by $m w d \&$ month is specific wave energy distribution by mean wave direction and by month at node point $\mathrm{No} 7, \mathrm{kWh} / \mathrm{m}$.

\section{EQUIPMENT CHOICE}

In cooperation with Riga Technical University, at least 108 current developments were considered. In the beginning, more than 109 installed and under development devices were examined [27]. Then the classification of equipment was made according to suitability of installation for onshore, nearshore and offshore. Afterwards, the type of equipment was selected from the perspective of options to elevate receiver and to position to $m w d$. Finally, the axial turbine with vertical axis and self-regulating blades (SAB) was chosen. 


\section{CONCEPT OF SELECTION OF TURBINE DIAMETERS}

Figure 3 shows a new type of turbine - an axial self-regulating blade hydrokinetic (ASRBHK) turbine. It was tested under laboratory conditions.

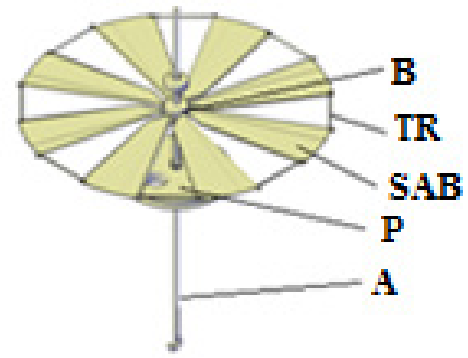

Fig. 3. ASRBHK turbine construction (B - bearing, $\mathrm{TR}$ - tensioning rubber, $\mathrm{SAB}$ - self-adjusting blade ( $\mathrm{SAB}), \mathrm{P}$ - pulley, $\mathrm{A}$ - axis) [28].

Various torqueses are formed on the ASRBHK turbine during its various phases and in the turbine wing positions. Turbine works more efficiently when the number of wave phases is as small as possible. Each wave has four phases. The smallest number of phases, which crosses the turbine wing, is two. For this reason, it is worth looking at the length of SAB depending on the wavelengths. Let us look at one of the areas of the Baltic Sea's Latvian EEZ (for example, the data of node point P1 in 2010) (Fig. 4).

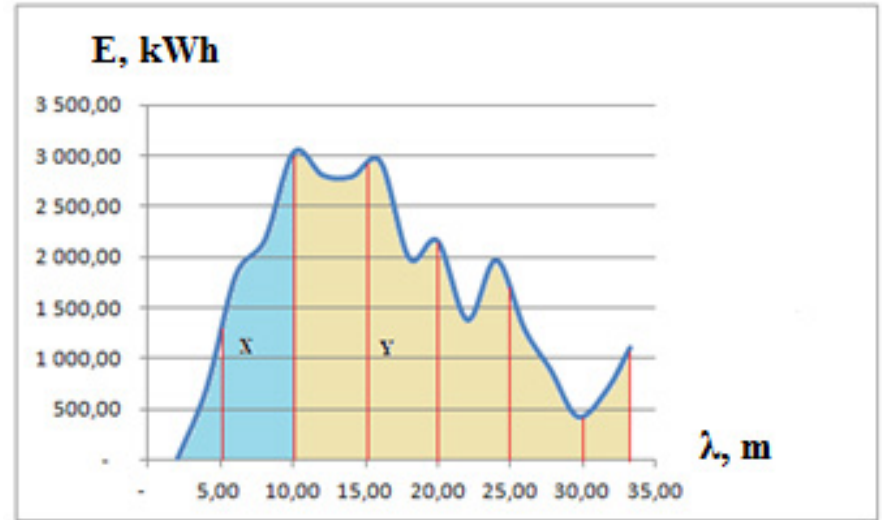

Fig. 4. Distribution wave energy at node point P1 2010 depending on $\lambda / 4(\mathrm{~m})$.

Figure 4 shows that enough wave energy will be in the area $X$ where $1 / 4$ of the wavelength will be $10 \mathrm{~m}$. This means that the maximal turbine diameter could be 20 $\mathrm{m}$. Meanwhile the minimal diameter would determine some other parameters like drop of efficiency and/or too high costs. In the area Y shown in Fig. 4, the turbine of any diameter will work with partial wave power. It should be deepened in order to avoid overloading. 


\section{TURBINE POWER CALCULATION}

To determine turbine power, we combine and stack two methods - an experimental one to determine turbine model power and a mathematical method to determine industrial-sized turbine power. In order to find out the parameters of the turbine model, turbine models were made for which the shape of the self-adjusting blade was sub-optimized. The laboratory wave stand had the ability to change the wave parameters $(H$ and $T)$. In order to determine the capacity of an industrial-sized turbine, we considered the specific power frequency of the potential P1 wave power plant in the Baltic Sea. This is essential for providing the turbine with optimum load. For the transition from the turbine model to the industrial size, let us use the Morozov's equation [24] before creating a special relationship more suitable for this mechanism.

In order to identify the duration of the waves of particular average power, we will create hourly statistics, for example, node point P1 2010 (Fig. 5).

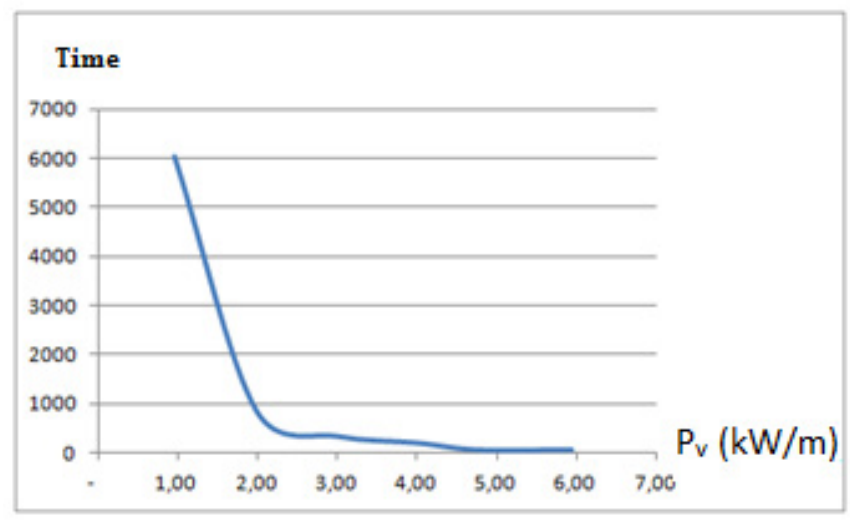

Fig. 5. Wave average hourly specific power $P_{v}(\mathrm{~kW} / \mathrm{m})$ statistics at node point $\mathrm{P} 1$ (2010).

By optimizing the peculiar incoming energy of the mentioned node point, the result was the optimum specific power of $1 \mathrm{~kW} / \mathrm{m}$.

The coefficient $\eta_{T}$ is used to determine the efficiency of transformation from wave energy to electricity and can be characterized by equitation (2):

$$
\eta_{T}=\eta_{V} \times \eta_{H} \times \eta_{P} \times \eta_{F} \times \eta_{L} \times \eta_{M} \times \eta_{E},
$$

where $\eta_{V}$ - the kinetic energy distribution coefficient in volume; $\eta_{H}$-the horizontal flow separation ratio $(0.5) ; \eta_{P}$ - the flow utilization factor for estimating the flow through the turbine (Beitz/Glauerts 0.5926) [29]; $\eta_{F}$ - the form factor $(\pi / 4) ; \eta_{L}-$ the turbine hydraulic efficiency; $\eta_{M}$ - the mechanical efficiency (bearing, seal 0.95); $\eta_{E}-$ the efficiency ratio of the electric generator (for calculations we will use 0.95).

Morozov's equation (6) describes the relationship of the known ASRBHK turbine $T_{1}$ model and geometric similar turbines $T_{n}$ with diameter $D_{n}(6)$ : 


$$
\eta_{L n}=\left(1-\left(1-\eta_{L 1}\right) \times \sqrt[5]{\frac{D_{1}}{D_{n}}}\right.
$$

where $\eta_{L n}$ - the efficiency coefficient of a geometrically similar turbine; $\eta_{L 1}-$ the efficiency ratio of known turbine; $D_{1}$ - the diameter of known turbine $(0.9 \mathrm{~m}) ; D_{n}-$ the diameter of the geometrically similar turbine.

Assuming $\eta_{T 1}$ and $\eta_{T n}$ expressions based on equation (5), dividing both of these equations with each other and by deducing the same variables we will express them as equation (7):

$$
\frac{\eta_{T 1}}{\eta_{T n}}=\frac{\eta_{L 1}}{\eta_{L n}}
$$

From (7) known turbines $\eta_{L I}$ :

$$
\eta_{L 1}=\frac{\eta_{T 1}}{\eta_{V} \cdot \eta_{H} \cdot \eta_{P} \cdot \eta_{F} \cdot \eta_{M} \cdot \eta_{E}}
$$

where all the values on the right of the equation are known. Thus, knowing $\eta_{L n}$, $\eta_{L I}$ and $\eta_{T I}$ from expression (8), the coefficient of utilization of the geometrically similar turbine $\eta_{T n}$ is calculated. Calculations of $\eta_{T}$ for ASRBHK turbine of different diameters from $1 \mathrm{~m}$ to $30 \mathrm{~m}$ with step in $1 \mathrm{~m}$ were made.

Turbine utilization rate was estimated based on turbine $\left(D=0.9 \mathrm{~m}, P_{w}=0.764\right.$ $\mathrm{W} / \mathrm{m}$ only) parameters. This means that incoming power of turbine $(D=9.0 \mathrm{~m})$ is only $0.08 \mathrm{~kW}$, turbine $(D=15.0 \mathrm{~m})$ is only $0.21 \mathrm{~kW}$ and turbine $(D=20.0 \mathrm{~m})$ is only $0.38 \mathrm{~kW}$. For more powerful waves, the turbine utilization factor will improve. For our further calculations we will use assumption that average turbine utilization rates are appropriately $D=9.0 \mathrm{~m}-0.25$.

\section{ECONOMIC ASPECTS}

\section{A. Forecasting Wave Energy Production}

Price forecasting is the basis for solving a wide range of important problems for planning and managing the energy sector, and feasibility study of wave energy production is not an exception. A great number of methods from different modelling families are used for analysis and planning questions [30]. Comprehensive reviews of pricing approaches are provided in the articles [30]-[32].

To analyze the feasibility of presented WPP, a net present value (NPV) and a payback period (PP) for the planning period $T_{p}$ (in our case 34 years) should be estimated. In NPV criteria value assessment, the greatest difficulty is related to calculation of the net cash flow $R_{t}$ because of the change of the energy prices over time. In our case, the $R_{t}(€)$ is calculated as follows: 


$$
R_{t}=P_{r a t, t} \cdot \tau \cdot L_{W P P} \cdot k \cdot C_{t},
$$

where $P_{\text {rat }, t}$ - rated specific wave power per hour $t, \mathrm{~kW} / \mathrm{m} ; \tau$ - the time step (1 hour); $L_{W P P}$ - the length of WPP, m; $k$ - the flow average utilization factor; $C_{t}-$ the predicted market price of electricity at hour $t,(€ / \mathrm{kWh})$.

In order to calculate NPV, it is necessary to describe changes in processes for many years ahead. This task leads to uncertainty and necessitates the use of the methods of the theory of stochastic processes. In our case, we assume that electricity prices can be forecast by using the Fourier series and white noise. It should be pointed out that the approach we use is only one of the possible approaches. The proof of its satisfactory accuracy and a more detailed description is given in our previous work [33]. 1.5\% increase in the annual average price is assumed. Moreover, the rated specific wave power is estimated for one year and does not change during the planning period.

\section{B. The Methodology of Feasibility Studies}

In general, energy planning issues are formulated in the form of profit maximization tasks. In this paper, we limit ourselves to using only the NPV [34]. The NPV could be formulated as an optimization task as follows:

$$
N P V\left(T_{p}\right) \rightarrow \max
$$

In our case we estimated two options of NPV:

1. Prosumer takes a credit in bank for WPP construction:

$$
\operatorname{NPV}\left(T_{p}\right)=-C_{\text {invest }}+\sum_{t=1}^{T_{P}} \frac{\left(R_{t}\right)-\left(\frac{C_{\text {invest }}}{T_{p}}+C_{\text {loan }, t} \cdot i_{\text {cred }}\right)}{\left(1+i_{d}\right)^{t}}
$$

where $C_{\text {invest }}$ - initial investments of WPP construction, $€ ; t$ - the planning year $(1$, $\left.2, \ldots T_{p}=34\right) ; C_{\text {loan }, t}$ - the outstanding loan amount of year $t, € ; i_{\text {cred }}-$ the credit rate, $\% ; i_{d}-$ the discount rate, the rate of return that could be earned on an investment in financial markets with a similar risk.

2. Prosumer does not take a loan:

$$
N P V\left(T_{p}\right)=-C_{\text {invest }}+\sum_{t=1}^{T_{p}} \frac{R_{t}}{\left(1+i_{d}\right)^{t}}
$$




\section{CASE STUDY AND RESULTS}

\section{A. Input Information}

In the case study, we considered wave potential of one sector (with parameters of node point P1 [23] of Latvian EEZ of the Baltic Sea. In this section, the early feasibility study of WPP P1 sector is presented. We estimate the economic criteria of WPS construction, such as NPV of cash flow and PP. Moreover, one of the goals of the study is to determine the coefficient $k$, at which the PP of this project will be 10 years. The NPV is calculated for two alternatives: Alternative 1 presumes taking a loan; Alternative 2 entails no loan. As a result, 42 scenarios are reviewed.

The necessary input parameters and investment cost of P1 sector are displayed in Table 2. It should be mentioned that data of total costs of one set is an assumption.

Table 2

Input Parameters of WPP at Sector P1 of the Baltic Sea

\begin{tabular}{|c|c|c|c|c|c|c|}
\hline $\begin{array}{c}\text { Specific wave } \\
\text { power, } P_{\text {rat.max }}, \\
\mathrm{kW} / \mathrm{m}\end{array}$ & $\begin{array}{c}\text { Length of } \\
\text { WPP, } L_{W P P} \\
\mathrm{~m}\end{array}$ & $\begin{array}{c}\text { Costs of } \\
\text { hydrokinetic } \\
\text { turbine, } \\
€ / \text { turbine }\end{array}$ & $\begin{array}{c}\text { Number of } \\
\text { turbines }\end{array}$ & $\begin{array}{c}\text { Total } \\
\text { investments } \\
\text { of WPP, M€ }\end{array}$ & $\begin{array}{c}\text { Discount } \\
\text { rate, } \%\end{array}$ & $\begin{array}{c}\text { Credit rate, } \\
\%\end{array}$ \\
\hline 7.67 & 19400 & 15000 & 2156 & 32.33 & 4.0 & 2.6 \\
\hline
\end{tabular}

Costs of one turbine were calculated on the basis of generators as a comparison with common diesel generator price to $\mathrm{kW} \times 3$ [35], which appreciate generator underwater working conditions, anchoring/elevating device and network connection. Working hours per year at full capacity in fact should be less because power station will take some shape. Therefore, in respect of $m w d$ increase some energy will be shaded.

B. Results

The resulting NPV curves are shown in Figs. 6 and 7.

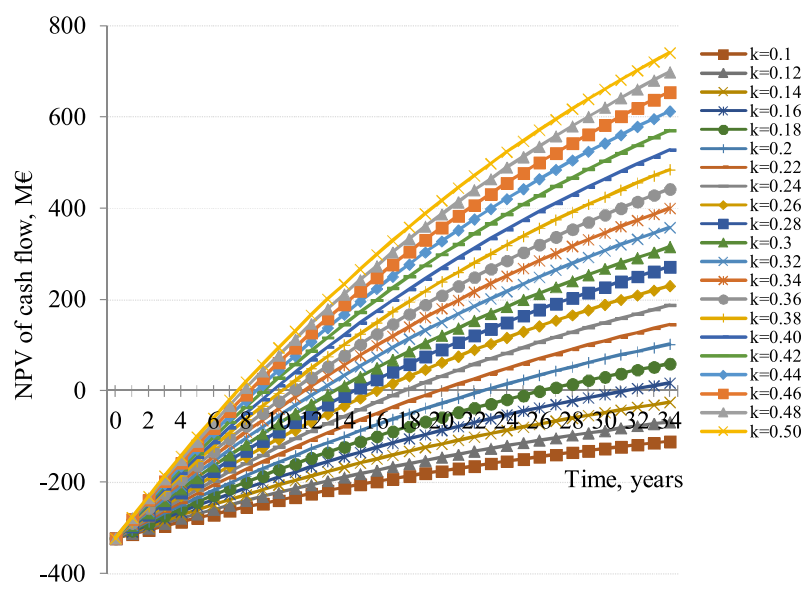

Fig. 6. NPV cash flow of P1 without loan. 


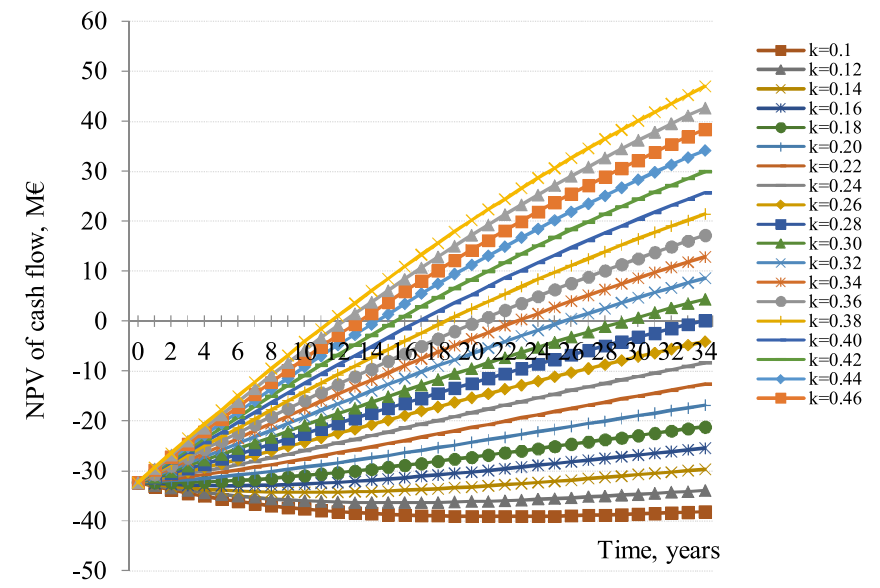

Fig. 7. NPV cash flow of P1 with loan.

Based on the assumptions and reviewed scenarios, the PP of WPP P1 investment varies from 7 years to more than 34 years. Analyzing Alternative 1 of NPV, it is viewed that in order to achieve a plant payback of 10 years, the utilization coefficient should be no less than 0.34 . According to the results of Fig. 7, the wave average utilization factor should be more than 0.50 .

It is also necessary to take into account that in calculations an average coefficient of wave utilization was adopted. In practice this coefficient will vary constantly depending on the turbine load.

Therefore, one of the objectives of the future research will be to accurately determine the wave utilization factor and its effect on wave energy production and the payback of the wave energy technology.

\section{CONCLUSIONS}

1. The dynamics of energy consumption and the related climate change are encouraging the increased use of renewable resources.

2. Free surface gravity waves could become an important source of renewable energy.

3. Wave potential is being studied in the world, including the Baltic Sea.

4. The recommendations of binding standards should be more respected in order to assess the potential of waves more precisely.

5. More than 1,000 patents are registered worldwide for wave transformation.

6. The vertical axis turbine operates under laboratory conditions.

7. More accurate economic calculations require input from higher TRL and power plant sketch designs.

8. In order to achieve a payback time of 26 years without a credit in the Baltic Sea power plant with nodal point P1 parameters, the turbine must have the flow utilization factor of 0.18 . 
The research has been supported by the European Regional Development Fund within the Activity 1.1.1.2 "Post-doctoral Research Aid" of the Specific Aid Objective 1.1.1 "To increase the research and innovative capacity of scientific institutions of Latvia and the ability to attract external financing, investing in human resources and infrastructure" of the Operational Programme "Growth and Employment" (No.1.1.1.2/VIAA/2/18/317).

The research has also been supported by the Ministry of Economics of the Republic of Latvia, project "Future-proof Development of the Latvian Power System in an Integrated Europe (FutureProof)”, project No. VPP-EM-INFRA-2018/1-0005.

\section{REFERENCES}

1. Real Time World Statistic. (n.d.). Available at https://www.worldometers.info/worldpopulation/

2. World Energy Consumption Since 1820 in Charts. (n.d.). Available at https:// ourfiniteworld.com/2012/03/12/world-energy-consumption-since-1820-in-charts/

3. Renewable Energy Statistics. (n.d.). Available at https://ec.europa.eu/eurostat/statisticsexplained/index.php/Renewable_energy_statistics\#Renewable_energy_produced_in_ the_EU_increased_by_two_thirds_in_2007-2017

4. Communication from the commission to the european parliament, the council, the european economic and social committee and the committee of the regions: Energy 2020. A strategy for competitive, sustainable and secure energy [COM(2010)639]. Available at https://ec.europa.eu/energy/en/topics/energy-strategy-and-energy-union/2020-energystrategy.

5. Global Energy \& CO2 Status Report (2018). The Latest Trends in Energy and Emissions in 2018. Available at https://www.iea.org/geco/emissions/.

6. NASA Earth Observatory. (n.d.). Available at https://earthobservatory.nasa.gov/worldof-change/DecadalTemp

7. Tapio, P., Varho, V., \& Heino, H. (2013). Renewable Energy in the Baltic Sea Region 2025. Journal of East-West Business, 19, 47-62. 10.1080/10669868.2013.779544.

8. Thomas, J., Barve, K.H., Dwarakish, G., \& Ranganath, L. (2015). A Review on Assessment of Wave Energy Potential. In National Conference on Futuristic Technology in Civil Engineering for Sustainable Development (178-186), 9 May 2015, Department of Civil Engineering, SJBIT.

9. Edenhofer, O., Pichs-Madruga, R., Sokona, Y., Seyboth, K., Matschoss, P., Kadner, S. ....\& von Stechow, C (2010). Special Report of the Intergovernmental Panel on Climate Change IPPC. Renewable Energy Sources and Climate Change Mitigation. United Kingdom and New York: Cambridge University Press.

10. ETIPOCEAN (n.d.). Ocean Energy Statistics 2018: Europe Leading the Sector. Available at https://www.etipocean.eu/news/ocean-energy-statistics-2019/

11. IRENA (2014). Wave Energy: Technology Brief. Available at https://www.irena.org/ publications/2014/Jun/Wave-energy

12. Rusu, E., \& Onea, F. (2018). A Review of the Technologies for Wave Energy Extraction. Clean Energy, 1. 10.1093/ce/zky003.

13. Magagna, D., \& Uihlein, A. (2015). Ocean Energy Development in Europe: Current 
Status and Future Perspectives. International Journal of Marine Energy, 11, 84-104. https://doi.org/10.1016/j.ijome.2015.05.001.

14. Melo AB (2010). Pico Power Plant: Perspectives for the Future? Available at http:// www.picoowc.net/files/33/new3_84d9ee44e457ddef7f2c4f25dc8fa865.pdf.

15. Ocean Energy Systems (2016). Annual Report Ocean Energy Systems 2016. Available at https://report2016.ocean-energy-systems.org/

16. ETIPOCEAN (n.d.). EU-funded Ocean Energy Projects Framework Programme 7 \& Horizon 2020. Available at https://www.etipocean.eu/assets/Uploads/170418-EUfunded-projects.pdf

17. Ingmarsson, P., \& Hüffmeier, J. (2019). 2030 and 2050 Baltic Sea Energy Scenarios Ocean Energy. RISE Research Institutes of Sweden, Swedish Agency for Marine and Water Management.

18. Soomere, T., \& Eelsalu, M. (2014). On the Wave Energy Potential along the Eastern Baltic Sea coast. Renewable Energy: An International Journal, 71, 221-233.

19. Mørk, G., Barstow, S., Kabuth, A., \& Pontes, M. (2010). Assessing the Global Wave Energy Potential. In ASME 2010 29th International Conference on Ocean, Offshore and Arctic Engineering. Shanghai, China. 3. 10.1115/OMAE2010-20473.

20. European Commission (n.d.). EU Strategy for the Baltic Sea Region. Available at https:// ec.europa.eu/regional_policy/lv/policy/cooperation/macro-regional-strategies/balticsea/

21. Avotiņš, A., Greivulis, J., \& Kalniņš, L. (2008). Baltijas jūras potenciāls viļ̣na enerğijas pārveidošanai. Energétika un elektrotehnika, 23, 213-224.

22. Jakabson, P. (2011). Mapping and Assessment of the United States Ocean. Wave Energy Electric Power Research Institute, Technical report.

23. Beriņš, J., Berinšš, J., \& Kalnačs, A. (2016). Wave Energy Potential in the Latvian EEZ. Latvian Journal of Physics and Technical Sciences, 3, 22-23.

24. Radziņš, Z., \& Zars, V. (1964). Hidrauliskās mašīnas un mehānismi. Latvijas Valsts izdevniecība.

25. National Date Buoy Centre (n.d.). Measurement Description and Units. Available at http://www.ndbc.noaa.gov/measdes.shtml

26. MK noteikumi. Nr.779 (17.08.2010.). Noteikumi par bāzes līniju punktu koordinātēm.

27. Beriňš, J. (2019). Ocean and Marine Energy Options and Development. Doctoral Thesis. Available at https://ortus.rtu.lv/science/lv/publications/29289

28. Beriņš, J., \& Beriņš, J. (2017). New Hydrokinetic Turbine for Free Surface Gravitational Wave Transformation. Latvian Journal of Physics and Technical Sciences, 6, 32-41.

29. Betz, A. (1966). Introduction to the theory of flow machines. NY: Pergamon Press.

30. Powell, W. B., \& Miesel, S. (2018). Tutorial on Stochastic Optimisation in Energy-Part II: An Energy Storage Illustration. IEEE Trans. Power Syst., 31(2), 1468-1475.

31. Petrichenko, R., Baltputnis, K., Sauhats, A., \& Soboḷevskis, D. (2017). District Heating Demand Short-Term Forecasting. In 2017 IEEE International Conference on Environment and Electrical Engineering and 2017 IEEE Industrial and Commercial Power Systems Europe (EEEIC / I\&CPS Europe), (pp. 1374-1378). 6-9 June 2017, Italy, Milan. 10.1109/EEEIC.2017.7977633.

32. Sauhats, A., Petrichenko, R., Broka, Z., Baltputnis, K., \& Soboḷevskis, D. (2016). ANNBased Forecasting of Hydropower Reservoir Inflow. In 57th International Scientific Conference on Power and Electrical Engineering of Riga Technical University (RTUCON 2016), 13-14 October 2016, Latvia, Riga. 10.1109/RTUCON.2016.7763129. Electronic ISBN: 978-1-5090-3731-5, USB ISBN: 978-1-5090-3730-8 
33. Petrichenko, L,., Sauhats, A., Petričenko, R., \& Bezrukovs, D. (2018). Long-Term Price Forecasting for the Cost-Benefit Analysis of Power Equipment. In 59th International Scientific Conference on Power and Electrical Engineering of Riga Technical University, 12-14 November 2018, Latvia, Riga. 10.1109/RTUCON.2018.8659888. Electronic ISBN: 978-1-5386-6903-7, USB ISBN: 978-1-5386-6902-0

34. Sauhats, A., Zemīte, L., Petrichenko, L., Moškins, I., \& Jasevičs, A. (2018). Estimating the Economic Impacts of Net Metering Schemes for Residential PV Systems with Profiling of Power Demand, Generation, and Market Prices. Energies, 11(11), 1-19. $10.3390 / \mathrm{en} 11113222$.

35. Energolukss (n.d.). Generators. Available at https://www.energolukss.lv/shop/product/ generators-sdmo-diesel-15000-te-xl-c-10kw-riteni-9349? category $=8$.

\title{
PRIEKŠIZPĒTES STADIJAS EKONOMISKAIS NOVĒRTËJUMS VIL,N̦U SPĒKSTACIJAI BALTIJAS JŪRĀ
}

\author{
J. Beriņ̌̌, L̦. Petričenko
}

Kopsavilkums

Šis raksts ir par vienu no alternatīvajiem enerğijas avotiem - brīvas virsmas gravitācijas viḷniem un to izmantošanu. Par galvenajiem enerǵijas izmantošanas ietekmes faktoriem tiek uzskatīts viḷnu potenciāls un tā pārveidošanas ierīču efektivitāte. Darba mērķi ir sekojoši: viḷnu potenciāla novērtēšana, enerğijas pārveidošanas modeḷa un turbīnas izvēle, kā arī ekonomisko kritēriju izvirzīšana, ņemot vērā viḷnu un cenu mainīgumu. Rakstā iekḷauts arī minētās turb̄inu elektrostacijas izmaksu teorētiskā novērtējuma apraksts.

11.09.2019. 